\title{
Resistance in wild tomatoes to larvae of a specialist herbivore, Keiferia lycopersicella
}

\author{
S. Y. H. Lin \& J. T. Trumble \\ Department of Entomology, University of California, Riverside, CA 92521, USA
}

Keywords: Keiferia lycopersicella, Lycopersicon hirsutum, L. hirsutum f. glabratum, food consumption, mining behavior, glandular trichomes, tomato

\begin{abstract}
Delayed larval development, higher mortality, and reduced leaf consumption by the tomato pinworm, Keiferia lycopersicella (Walsingham) (Lepidoptera: Gelechiidae), were observed on two related wild tomatoes, Lycopersicon hirsutum Humb. \& Bonpl. (LA 361) and L. hirsutum f. glabratum C. M. Mull (PI 134417), when compared with the commercial variety, L. esculentum cv. VFN 7718. The exudate of type VI trichomes of these wild accessions provided significant antibiotic effects against the first larval instar of $K$. lycopersicella: $95-97.5 \%$ mortality occurred on foliage with the trichomes intact, versus $5.6-30 \%$ mortality on foliage where trichome heads were removed. Basal cells of type VI trichomes and other epidermal cells as well as most of the palisade mesophyll cells of L. hirsutum f. glabratum, were not consumed by K. lycopersicella larvae, suggesting these structures also contain deterrent chemicals. Similar results were not evident for $L$. esculentum and L. hirsutum.
\end{abstract}

\section{Introduction}

Keiferia lycopersicella, the tomato pinworm, is an oligophagous insect which feeds exclusively on Solanaceae under field conditions. The cultivated tomato Lycopersicon esculentum Mill. is the most suitable host (Batiste \& Olson, 1973). Since being introduced from Mexico in 1923, K. lycopersicella has spread throughout much of the southern United States (Jones, 1923; Batiste et al., 1970) resulting in substantial economic losses to fresh market tomatoes in southern California, Florida, and Texas (Oatman, 1970; Schuster, 1977a; Wellik et al., 1979). Chemical control has been the major strategy for $K$. lycopersicella suppression, but plant resistance has been receiving considerable attention as a management tool compatible with other control techniques as part of integrated pest management (IPM) systems (Maxwell \& Jennings, 1980; Hedin, 1983).

Two wild tomatoes, L. hirsutum Humb. \& Bonpl. and L. hirsutum $\mathrm{f}$. glabratum C. M. Mull have been reported to be resistant to $K$. lycopersicella in field trials in Florida (Schuster, 1977b; Schuster et al., 1979), but the mechanisms of resistance have not yet been clearly defined. Resistance to Heliothis zea larvae in several accessions of these two wild tomatoes, was apparently due to an antibiotic factor in the leaves which caused high mortality (Fery \& Cuthbert, Jr., 1975). Such antibiotic factors may include glycoalkaloids which have been shown to depress the growth, development, and survival of several lepidopterous pests (Weinberg, 1980). Recently, a nonalkaloid antibiotic, 2-tridecanone, has also been isolated from the foliage surface of L. hirsutum f. glabratum Pl 134417 and found to adversely affect insect larvae (Kennedy \& Yamamoto, 1979; Williams et al., 1980; Dimock \& Kennedy, 1983; Kennedy \& Sorenson, 1985).

The resistance mechanisms involved in tomato plants are rarely simple, and the adaptation of a specialist herbivore to food plants goes beyond 
mere tolerance of the defensive substances (Edwards \& Wratten, 1980). Because $K$. lycopersicella early instar larvae feed almost exclusively on leaf tissue, larval dependence on this food source might be utilized in development of $K$. lycopersicella by comparing leaf consumption, first-instar $K$. lycopersicella larval mining (feeding) behavior, development and survival in each larval instar on two accessions of wild tomato and one susceptible commercial line.

\section{Materials and methods}

All $K$. lycopersicella larvae used in these studies were from a laboratory colony which was established in 1982 with insects collected from the fresh market tomato, cv. 'VFN 7718' (Petoseed) in Orange County, California. The colony was maintained on plants of the same variety. Tests were conducted at $27 \pm 1{ }^{\circ} \mathrm{C}$ and a photophase-scotophase cycle of $16-8 \mathrm{~h}$. Test plants included the commercial tomato variety, L. esculentum Mill. (Petoseed 'VFN 7718'), and two accessions of wild tomato, L. hirsutum (LA 361) obtained from Dr. C. Rick (Univ. Calif. Davis) and L. hirsutum f. glabratum (Pl 134417) obtained from Dr. G. Kennedy (North Carolina State Univ.). All varieties were grown in the greenhouse using U.C. soil mix (Matkin \& Chandler, 1957) supplemented with a slow release fertilizer (Osmocote ${ }^{\circledR}$ 14-14-14), and a liquid micronutrient solution supplied twice monthly. Greenhouse plants were maintained at $23.9 \pm 6^{\circ} \mathrm{C}$, 60 to $75 \%$ relative humidity, and a $16 \mathrm{~h}$ photophase. Two-months old plants were used for all experiments.

Statistical analyses of data from the following tests were performed using analysis of variance followed by Duncan's multiple range test (DMRT) unless otherwise noted. An arcsine transformation was used prior to analysis whenever appropriate to normalize the data.

Development and mortality. Six replicates of 30 $K$. lycopersicella larvae were tested on each of the three tomato accessions (180 larvae/variety). Neonate $K$. lycopersicella were allowed to crawl $(<5 \mathrm{~mm})$ onto detached leaflets (the fifth \& sixth leaves from the bottom of the plant) of $L$. esculentum, L. hirsutum and L. hirsutum f. glabratum en- closed in glass petri dishes (one larva/leaflet/dish). This technique avoided the high mortality associated with placing larvae directly on the leaflets, which artificially caused excessive contact with the trichomes. Leaflet petioles were inserted in small blocks of $5 \%$ agar which were replaced every 2 days. This method maintained leaflets in a suitable condition for feeding for at least 5 days. Fresh leaflets were provided for each instar to transfer themselves, thereby avoiding handling mortality. Developmental times and mortality were recorded daily for each life stage through adult emergence. To determine if either nitrogen or water content in each variety was related to survival and development, total organic nitrogen content was determined using a micro-Kjeldahl technique (McKenzie $\&$ Wallace, 1954), and the water content of leaves was recorded from four compounds leaves (fifth \& sixth from the bottom) of four plants per accession.

Food consumption. Leaf consumption was evaluated for the first through fourth instars (L1- L4) of $K$. lycopersicella. A replicate consisted of 100 newly eclosed larvae per accession. Ten randomly chosen $K$. lycopersicella were frozen, dried, and weighed at the onset and completion of each developmental stage, including the pupal stage. This test was replicated four times, for a total of 80 $K$. lycopersicella per developmental stage per accession.

A pair of leaflets was chosen from symmetrical, opposite-paired leaflets of leaves from each accession. Such leaves were not significantly different in dry weight ( $\mathrm{t}$ test, $\mathrm{P} \leq 0.05$ ). One of the pair was weighed and inserted in an agar block and supplied to the larvae. The dry weight of this leaflet was estimated by multiplying its fresh weight by the percent dry matter determined for the other leaflet of the pair. The leaflets fed to larvae were first changed at the pre-molting stage (Waldbauer, 1968) of first and second instar, and then changed daily when larvae reached third and fourth instars. Determination of each instar was based on head capsule size (Waltz, 1948). Uneaten leaf material was collected, frozen, and subsequently dried at $80^{\circ} \mathrm{C}$ to constant weight. After larvae entered the premolt stage, they were frozen, dried at $80^{\circ} \mathrm{C}$ and then weighed. The same procedures were utilized for determining food consumption of third and fourth instar larvae. Lar- 
vae were collected at the onset of the prepupal stage, and transferred to clean sand for pupation. Twenty-four hours after pupation, the sand and silk pupal cases were removed from the pupae by gentle shaking in a $10 \%$ bleach solution, then rinsing with distilled water. Pupae were frozen, dried at $80^{\circ} \mathrm{C}$, and then weighed.

All calculations were based on dry weight determinations. The initial dry weights ( $40 \mathrm{~K}$. lycopersicella/developmental stage/accession) and the final dry weights ( $40 \mathrm{~K}$. lycopersicella/developmental stage/accession) were calculated based on means of groups of $K$. lycopersicella that developed concurrently under the same experimental conditions. Mean dry weights were calculated by the weighed average method described by Waldbauer (1964). Leaf area was determined using a Li-Cor LI-3000 leaf area meter (Li-Cor Corp., Lincoln, Nebraska). The percentage of leaf area mined by first and second instars was than calculated.

K. lycopersicella mining behavior. Ten leaflets of each accession mined by first instar larvae were prepared using a modified plastic embedding technique (Burns \& Bretschneider, 1981; O'Brien \& McCully, 1981). Mined leaflet sections were fixed with $2 \%$ glutaraldehyde in $50 \mathrm{mM}$ phosphate buffer $\left(\mathrm{pH} \mathrm{7.2)} \mathrm{and} \mathrm{stored} \mathrm{overnight} \mathrm{at} 5^{\circ} \mathrm{C}\right.$. The tissue was then dehydrated in an ethanol series, embedded in glycol methacrylate plastic, and serially sectioned at $3 \mu \mathrm{m}$ with a glass-knife microtome. Sections were stained in Toluidine Blue $\mathrm{O}$ in a $\mathrm{pH} 7.0$ buffer. The slides were examined with a phase con- trast microscope. Photographs of sections were taken with Kodak ${ }^{\mathrm{TM}}$ Technical Pan Film 2415, using a Zeiss $^{\mathrm{TM}}$ microscope equipped with a Nikon $^{\mathrm{TM}}$ multiphoto system.

Role of glandular trichomes in resistance to K. lycopersicella. To determine whether the glandular trichomes on the foliage of L. hirsutum f. glabratum and L. hirsutum were responsible for $K$. lycopersicella resistance, neonate larvae were placed on foliage from which the trichome exudate had been removed by gently wiping both surfaces of excised leaflets with cotton moistened with $70 \%$ ethanol (after Dimock \& Kennedy, 1983). Leaflets were then rinsed in distilled water to remove the ethanol and examined under a dissecting microscope to verify that all glandular trichome heads had been removed. Control larvae were allowed to feed on untreated L. hirsutum f. glabratum, L. hirsutum and $L$. esculentum foliage (trichome heads intact). In all tests, larvae were individually confined on leaflets within scintillation vials; leaflet petioles were inserted in 5\% agar blocks to maintain leaf turgor. Larval mortality was recorded at $24 \mathrm{~h}$. The experiment was replicated six times with 30 larvae per replicate.

\section{Results and discussion}

Development and mortality. Developmental times and cumulative percent mortality of $K$. lycopersicella on the three tomato varieties are presented in Table 1. Although no significant differences in in-

Table 1. Developmental days ${ }^{d}$ and cumulative $\%$ mortality ${ }^{b}$ of $K$. lycopersicella from first instar to adult emergence on excised follage of three tomato accessions. L1, L2, L3 and L4: 1st, 2nd, 3rd and 4th instar larvae.

\begin{tabular}{llrr}
\hline Life state & \multicolumn{1}{c}{ Developmental days $( \pm$ s.e.)/cumulative $\%$ mortality } \\
\cline { 2 - 4 } & L. esculentum & L. hirsutum & $\begin{array}{c}\text { L. hursutum } \\
\text { f. glabratum }\end{array}$ \\
\hline L1 & $3.0 \pm 1.0 / 9.4 \mathrm{a}$ & $4.0 \pm 1.0 / 75.0 \mathrm{~b}$ & $5.5 \pm 1.0 / 85.0 \mathrm{~b}$ \\
L2 & $3.0 \pm 1.0 / 9.4 \mathrm{a}$ & $5.0 \pm 1.0 / 82.8 \mathrm{~b}$ & $4.0 \pm 1.0 / 89.4 \mathrm{~b}$ \\
L3 & $4.0 \pm 0.5 / 9.4 \mathrm{a}$ & $5.5 \pm 1.0 / 82.9 \mathrm{~b}$ & $6.0 \pm 2.0 / 91.7 \mathrm{~b}$ \\
L4 & $4.0 \pm 0.5 / 9.4 \mathrm{a}$ & $5.0 \pm 1.0 / 86.1 \mathrm{~b}$ & $6.5 \pm 2.0 / 92.2 \mathrm{~b}$ \\
pupae & $7.0 \pm 1.0 / 9.4 \mathrm{a}$ & $11.0 \pm 2.0 / 86.7 \mathrm{~b}$ & $13.0 \pm 2.0 \mathrm{~b} / 92.8 \mathrm{~b}$ \\
Total & $21.0 \pm 1.0 / 9.4 \mathrm{a}$ & $30.5 \pm 1.5 / 89.4 \mathrm{~b}$ & $35.5 \pm 1.5 \mathrm{5} / 92.8 \mathrm{~b}$ \\
\hline
\end{tabular}

a Total developmental time on wild accessions significantly different from developmental time on L. esculentum at P $\leq 0.01$, DMRT

b Mortalities calculated from 6 replicates of 30 larvae/accession; means in rows followed by same letter not significantly different at the $\mathrm{P} \leq 0.05$ level, arcsine transformation, DMRT.

- Developmental time significantly different from $L$. esculentum, P $\leq 0.05$, DMRT. 
dividual instar developmental times were observed between tomato varieties, developmental rates were consistently faster on the commercial variety. Collectively this effect was significant $(P \leq 0.01$, DMRT), with larval growth requiring an additional $5.5-8$ days on the wild accessions. Similar results were also evident for pupal developmental times with pupae from wild accessions requiring significantly more time $(P \leq 0.01$, DMRT).

The water content and total nitrogen of host material did not appear to be major factors limiting $K$. lycopersicella development on the wild tomatoes. Water content of foliage was similar for all plants, averaging $82.7 \%$ in L. hirsutum, $84.57 \%$ in L. hirsutum f. glabratum, and $86.2 \%$ in L. esculentum, and probably had little effect on host acceptance or suitability (Scriber, 1977). Percent nitrogen of leaves was not significantly different between varieties ( $4.2 \%$ in L. esculentum, $4.3 \%$ in L. hirsutum and $5.0 \%$ in L. hirsutum f. glabratum). However, the Kjeldahl technique is used to determine total nitrogen, and does not measure potential differences in soluble protein concentration or free amino acids, as well as other secondary compounds (e.g. tomatine), any of which could affect host suitability (Roddick, 1974; Scriber, 1984). Since the distribution among the different forms of nitrogenous compounds in these varieties could easily differ without affecting the total nitrogen content, additional research is necessary to clarify the possible effect of these compounds on $K$. lycopersicella development and survival.

The cumulative mortality of $K$. lycopersicella on the wild accessions was significantly higher than on the commercial variety (Table 1 ). The primary cause of mortality to $K$. lycopersicella on the wild tomatoes was associated with the entrapment of first instars in the sticky exudate of type VI glandu- lar trichomes (described by Luckwill, 1943) which are the most abundant trichomes on the leaf surface. When $K$. lycopersicella ruptured the type VI trichomes of wild accessions they initially became physically attached to the leaf surface, then subsequently died. Although density of type VI glandular trichomes on the leaf surface of the commercial variety $\left(8.1 / \mathrm{mm}^{2}\right)$ was the greatest of the three accessions $\left(5.7 / \mathrm{mm}^{2}\right.$ on $L$. hirsutum f. glabratum and $2.6 / \mathrm{mm}^{2}$ in L. hirsutum), K. lycopersicella larvae usually escaped from the sticky exudate and then penetrated the leaves. This suggested that the exudate of type VI trichomes in these wild accessions either contained more toxic component or had greater adhesive properties.

Food consumption. The percentage of leaf area mined by first-instar larvae (L1) and second-instar larvae (L2) in the wild tomatoes was approximately three times less than in 'VFN 7718' (Table 2). The lower percentage of area mined by $\mathrm{L} 1-\mathrm{L} 2$ in the wild accessions reflected the significant reductions in dry weight ingested ( $P \leq 0.05$, DMRT) as compared with the commercial variety (Table 2). As larval size increased, the differences between wild and

Table 3. Dry weights of last larval instars and pupae of tomato pinworm on selected tomato varieties.

\begin{tabular}{|c|c|c|c|}
\hline \multirow[t]{2}{*}{ Variety } & \multicolumn{3}{|c|}{ Dry weight $(\mu \mathrm{g})^{*} \pm$ s.e. } \\
\hline & Last instar & q & $\infty$ \\
\hline $\begin{array}{l}\text { L. hirsutum } \\
\text { L. hirsutum }\end{array}$ & $1.7 \pm 0.2 b$ & $2.9 \pm 0.1 \mathrm{~b}$ & $1.4 \pm 0.0 \mathrm{~b}$ \\
\hline f. glabratum & $1.4 \pm 0.1 \mathrm{~b}$ & $2.1 \pm 0.1 b$ & $1.0 \pm 0.0 \mathrm{~b}$ \\
\hline L. esculentum & $2.5 \pm 0.8 \mathrm{a}$ & $3.9 \pm 0.1 \mathrm{a}$ & $1.9 \pm 0.1 \mathrm{a}$ \\
\hline
\end{tabular}

* Significance as in Table 2.

Table 2. Food consumption* of each larval stage of the tomato pinworm on three tomato accessions.

\begin{tabular}{|c|c|c|c|c|}
\hline \multirow[t]{2}{*}{ Accession } & \multirow{2}{*}{$\frac{\% \text { Mined area }}{\mathrm{L} 1-\mathrm{L} 2}$} & \multicolumn{3}{|c|}{ Dry weight ingested $(\mathrm{mg}) /$ larvae \pm s.e. } \\
\hline & & $\mathrm{L} 1-\mathrm{L} 2$ & L3 & $\mathrm{L} 4$ \\
\hline $\begin{array}{l}\text { L. hirsutum } \\
\text { L. hirsutum }\end{array}$ & $0.006 \mathrm{~b}$ & $0.051 \pm 0.004 b$ & $1.031 \pm 0.003 b$ & $2.055 \pm 0.004 b$ \\
\hline f. glabratum & $0.005 b$ & $0.028 \pm 0.001 b$ & $1.021 \pm 0.003 b$ & $2.041 \pm 0.004 b$ \\
\hline L. esculentum & $0.018 \mathrm{a}$ & $0.234 \pm 0.011 \mathrm{a}$ & $1.842 \pm 0.005 a$ & $2.934 \pm 0.003 a$ \\
\hline
\end{tabular}

* Significancy, see Table 1. 

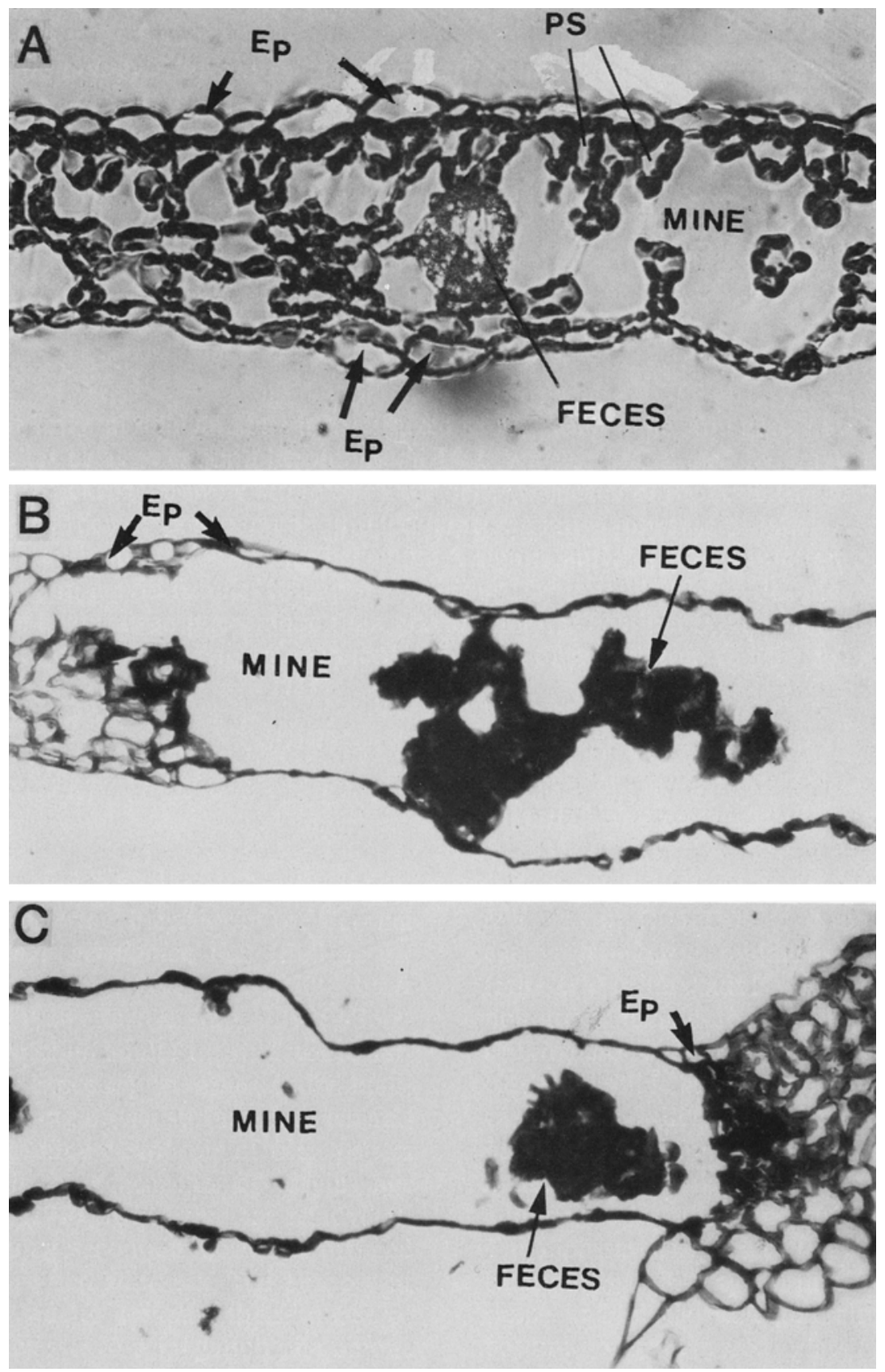

Fig. I. Photomicrographs (250x) of mines of first instar of K. lycopersicella in: A) L. hirsutum f. glabratum; B) L. hirsutum and; C) $L$. esculentum. Note that most epidermal cells (Ep) and mesophyll cells in $L$. hirsutum and $L$. esculentum were consumed. In contrast, epidermal cells on both upper and lower surfaces, and most of palisade cells (PS) of L. hirsutum f. glabratum were not disrupted. 
commercial accessions in dry weight of food consumed decreased from 8.3 times in $\mathrm{L} 1-\mathrm{L} 2$ to 1.4 times during the fourth instar. The cumulative effects of feeding on wild accessions resulted in significant reductions in body weights of last-instar larvae, and both male and female pupae (Table 3 ).

K. lycopersicella mining behavior. First instar larvae mining in leaves of the resistant species $L$. hirsutum f. glabratum consumed the spongy mesophyll cells, but avoided the epidermal cells and most of the palisade mesophyll cells in all ten of the leafmines sectioned (Fig. 1A). This differed from $K$. lycopersicella mining in the other accessions (Fig. 1, B-C), where epidermal and mesophyll cells were consumed, leaving only the cuticular layer. Kennedy \& Dimock (1983) established that most 2-tridecanone was concentrated in the glandular trichomes and leaf surface of $L$. hirsutum f. glabratum. Our results suggest that allelochemics might also be present in the basal cells of type VI glandular trichomes and other epidermal cells of L. hirsutum f. glabratum.

Role of glandular trichomes in resistance to K. lycopersicella. Larval survival on foliage of wild accessions was significantly improved $(\mathrm{P} \leq 0.05$, $\mathrm{t}-$ test) when the heads of the glandular trichomes were removed. $K$. lycopersicella suffered $97.5 \%$ and $95.0 \%$ mortality on control (trichome heads intact) foliage of L. hirsutum f. glabratum and L. hirsutum, respectively, compared with only $30 \%$ and $5.6 \%$ mortality on foliage where the trichome heads had been removed. These results are consistent with those of Dimock \& Kennedy (1983), which indicated that toxic compounds were contained in the glandular trichomes of these wild tomatoes. The glandular trichomes in commercial tomatoes were less effective defensively against $K$. lycopersicella ( $9.2 \%$ mortality). This may be related to the absence of 2-tridecanone in commercial tomatoes (Williams et al., 1980) or to the lack of other defensive compounds.

\section{Conclusions}

Collectively, these results suggest that $L$. hirsutum and L. hirsutum f. glabratum could provide sources for breeding tomato varieties resistant to
$K$. lycopersicella. The demonstrated reductions in $K$. lycopersicella food consumption and weight could reasonably be expected to adversely affect adult fecundity and longevity. Coupled with the growth-limiting effects of increased developmental times and significantly reduced survival, plant resistance alone could potentially provide adequate and economic levels of $K$. lycopersicella suppression. Although breeding programs for incorporation of these resistance sources from wild tomatoes into commercially desirable varieties appear to offer particular promise, the possibilities of inducing insect resistance to natural chemicals in glandular trichomes, and of negatively affecting beneficial organisms and tomato fruit quality should not be ignored (Waiss et al., 1977; Campbell \& Duffey, 1979; Stipanovic, 1983).

\section{Acknowledgments}

The authors thank Drs. J. Kumamoto, G. Walker, W. Osbrink, B. Martens and Mr. B. Wiesenborn and B. Moar for criticism, and Dr. G. G. Kennedy for earlier revision. Help with the plastic sectioning method was provided by Dr. D. DeMason and Mr. J. Stillman. Thanks to B. Martens for translating the summary into German.

\section{Zusammenfassung}

Resistenz bei wilden Tomaten gegen die Larven eines Nahrungsspezialisten, Keiferia lycopersicella

Zwei wilde Tomatenarten, Lycopersicon hirsutum Humb. \& Bonpl. (LA 361) und Lycopersicon hirsutum f. glabratum C. M. Müll. (Pl 134417), wurden mit einer kommerziell genutzten Sorte, $L y$ copersicon esculentum $\mathrm{cv}$. VFN 7718, im Hinblick auf ihre Eignung als Wirte für die stenotroph auf Tomaten lebende Herbivorenart Keiferia lycopersicella (Walsingham) (Lepidoptera: Gelechiidae), vergleichend untersucht. $K$. lycopersicella zeigte auf beiden wilden Arten im Vergleich zu $L$. esculentum eine Verminderung des Konsums an Blattmasse, Verzögerung der Larvalentwicklung und gesteigerte Mortalität.

Die höchsten Mortalitätsraten traten im ersten Larvenstadium auf, wobei die Drüsenhaare der wil- 
den Arten eine Schlüsselrolle als Mortalitätsfaktoren spielten. Die Ausscheidungen der Drüsenhaare vom Typ VI zeigten bei den wilden Varietäten signifikant abiotische Effekte gegen Eilarven von $K . l y$ copersicella: $95-97.5 \%$ Mortalität konnte auf Blättern mit intakten Trichomen beobachtet werden, während auf Blättern, bei denen der apikale Drüsenteil der Trichome entfernt worden war, die Mortalität nur $5.6-30 \%$ betrug.

Blattquerschnitte zeigten, daß die blattminierenden jungen Larvenstadien von $K$. lycopersicella in der kommerziellen Sorte unterschiedslos das gesamte innere Blattgewebe konsumierten; dagegen wurden in $L$. h. glabratum die Basalzellen der Trichome vom Typ VI sowie alle übrigen Epidermiszellen und der überwiegende Teil des Palisadenparenchyms nicht verzehrt. Es darf daher angenommen werden, daß diese Strukturen in den Blättern von $L$. h. glabratum fraßhemmende Substanzen enthalten. Diese Studie ermutigt die Einbeziehung wilder Tomaten in die Bemühungen zur Züchtung von Tomatensorten mit Resistenz gegen K. lycopersicella.

Mögliche negative Begleiterscheinungen, wie z.B. Einflüsse auf Nutzarthropoden, Veränderungen in der Qualität der Fruchte oder etwaige Resistenzbildung von Insekten gegen die Wirkstoffe der Drüsenhaare sollten dabei allerdings nicht vernachlässigt werden.

\section{References}

Batiste, W. C. \& W. H. Olson, 1973. Laboratory evaluation of some solanaceous plants as possible hosts for tomato pinworm. J. econ. Entomol. 68: 109-111.

Batiste, W. C., J. Joos \& R. C. King, 1970. Studies on sources of the tomato pinworm attacking tomatoes in northern California. J. econ. Entomol. 63: 1484-1486.

Burns, W. A. \& A. Bretschneider, 1981. Thin is $1 \mathrm{n}$ : plastıc embedding of tissue for light microscope. Educational Products Division Amer, Soc. Clinical Patholog1sts, Chicago: $52 \mathrm{pp}$.

Campbell, B. C. \& S. S. Duffey, 1979. Tomatine and parasitıc wasps: potential incompatibility of plant antibiosis with biological control. Science 205: 700-703.

Dimock, M. B. \& G. G. Kennedy, 1983. The role of glandular trichomes in the resistance of Lycopersicon hirsutum $\mathrm{f}$. glabratum to Heliothis zea. Entomol. exp. appl. 33: $263-268$.

Edwards. P. J. \& S. D. Wratten, 1980. Ecology of insect-plant interactions. The Institute of Biology's Studies in Biology, No. 121. Camelot Press Ltd., London, Great Britain: 59 pp.
Fery, R. L. \& F. P. Cuthbert, Jr, 1975. Factors affecting evaluation of fruitworm resistance in the tomato. Am. Soc. Hort. Sci. 98: $457-459$.

Hedin, P. A., 1983. Plant resistance to insects. Amer. Chem. Soc. Washington D.C.: 375 pp.

Jones, T. H., 1923. The eggplant leafminer Phthorimaea glochinella Zeller. J. Agric. Res. U.S. Dep. Agric. 26: $567-625$.

Kennedy, G. G. \& M. B. Dimock, 1983. 2-Tridecanone: a natural toxicant in a wild tomato responsible for insect resistance. In: J. Miyamato \& P. C. Kearney (eds), Pesticide Chemistry: Human Welfare and the Environment, Vol. 2. Pergamon Press, Tokyo: $372 \mathrm{pp}$.

Kennedy, G. G. \& C. F. Sorenson, 1985. Role of glandular trichomes in the resistance of Lycopersicon hirsutum $\mathrm{f}$. glabratum to Colorado potato beetle (Coleoptera: Chrysomelidae). J. econ. Entomol. 78: 547-551.

Kennedy, G. G. \& R. T. Yamamoto, 1979. A toxic factor causing resistance in a wild tomato to the tobacco hornworm and some other insects. Entomol, exp. appl. 26: 121-126.

Luckwill, L. C., 1943. The genus Lycopersicon; an historical, biological and taxonomic survey of the wild and cultivated tomatoes. Aberdeen Univ. Studies No. 120: 44 pp.

Matkin, O. A. \& P. A. Chandler, 1957. The U.C.-type soil mixes. In: F. Baker (ed.), The U.C. system for producing healthy container grown plants. Calif. Agric. Exp. Stn. Man. 23: 332 pp.

Maxwell, F. G. \& P. R. Jennings, 1980. Breeding Plants Resistant to Insects. Wiley-Interscience Publ. New York: $683 \mathrm{pp}$.

McKenzie, H. A. \& H. S. Wallace, 1954. The Kjeldahl determination of nitrogen: a critical study of digestion conditions temperature, catalyst, and oxidizing agent. Aust. J. Chem. 7: $55-70$.

Oatman, E. R., 1970. Ecological studies of the tomato pinworm on tomato in southern California. J. econ. Entomol. 63: $1531-1534$.

O'Brien, T. P. \& M. C. McCully, 1981. The Study of Plant Structure: Principles and Selected Methods. Melbourne, Australia: $357 \mathrm{pp}$.

Roddick, J. D., 1974. The steroidal glycoalkaloid x-tomatine. Phytochemustry 13: 9-25.

Schuster, D. J., 1977a. Effect of tomato cultivars on insect damage and chemical control. Fla. Entomol, 60: 227-232.

Schuster, D. J., 1977b. Resistance in tomato accessions to the tomato pinworm. J. Econ. Entomol. 70: 434-436.

Schuster, D. J., V. H. Waddill, J. J. Augustine \& R. B. Volin, 1979. Field comparisons of Lycopersicon accessions for resistance to the tomato pinworm and vegetable leafminer. J. Am. Soc. Hort. Sci. 104: 107-172.

Scriber, J. M., 1977. Limiting effects of low-water content on the nitrogen utilization, energy budget, and larval growth of Hyalophora cecropıa (Lepidoptera: Saturniidae). Oecologia (Berl.) 28: 269-287.

Scriber, J. M., 1984. Host plant suitability. In: R. T. Cardé \& W. J. Bell (eds), Chemical Ecology of Insects. Chapman Hall Ltd., London: $524 \mathrm{pp}$.

Stipanovic, R. D., 1983. Function and chemistry of plant trichomes and glands in insect resistance: protective chemicals in plant epidermal glands and appendages. In: P. A. Hedin (ed.), Plant Resistance to Insects. ACS Symposium Series 208, Washington, D.C.: $255 \mathrm{pp}$.

Waiss, Jr., A. C., B. G. Chan \& C. A. Elliger, 1977. Host plant 
resistance to insects. In: P. A. Hedin (ed.), Host Plant Resistance to Pests. ACS Symposium Series 62. Washington, D.C.: $286 \mathrm{pp}$.

Waldbauer, G. B., 1964. The consumption, digestion and utilization of solanaceous and non-solanaceous plants by larvae of the tobacco hornworm, Protoparce sexta (Johan) (Lepidoptera: Sphingidae). Entomol. exp. appl. 7: 253-269.

Waltz, A. J., 1948. Some studies on the life history of the tomato pinworm, Keiferia lycopersicella (Busck). M.S. Thesis, Univ. Calif., Berkeley: 47 pp.

Weinberg, H. L., 1980. Effects on Lepidopterous larvae of the tomato alkaloids tomatine and tomatidine. $\mathrm{Ph} . \mathrm{D}$. Thesis, Univ. Calif., Davis: 70 pp.

Wellik, M. J., J. E. Slosser \& R. D. Kirby, 1979. Evaluation of procedures for sampling Heliothis zea and Keiferia lycopersicella on tomato. J. Econ. Entomol. 72: 777-780.

Williams, W. G., G. G. Kennedy, R. T. Yamamoto, J. D. Thacker \& J. Boedner, 1980. 2-Tridecanone: a naturally occurring insecticide from the wild tomato Lycopersicon hirsutum $\mathrm{f}$. glabratum. Science 107: 888-889.

Accepted: December 9, 1985. 